Pak. j. sci. ind. res. Ser. A: phys. sci. 2016 59(2) 83-89

\title{
Effect of Processing on Physicochemical Properties and Fatty Acid Composition of Fluted Pumpkin (Telfairia occidentalis) Seed Oil
}

\author{
Jacob Olabode Alademeyin and Jacob Olalekan Arawande* \\ Department of Science Laboratory Technology, Rufus Giwa Polytechnic, Owo, Ondo State, Nigeria
}

(received February 17, 2015; revised August 18, 2015; accepted August 19, 2015)

\begin{abstract}
This paper reports the physicochemical properties and fatty acid composition of the seed oil extracted from fluted pumpkin (Telfairia occidentalis). The extracted oil was degummed, neutralised and bleached. The oil yield was $42.26 \pm 0.20 \%$. The specific gravity (at $25^{\circ} \mathrm{C}$ ) of the oil was $0.923 \pm 0.003$ and the refractive index (at $25^{\circ} \mathrm{C}$ ) was $1.475 \pm 0.002$. Processing of the crude oil resulted in progressive decrease in turbidity, colour, free fatty acid, acid value, peroxide value and saponification value. However, there was increase in smoke point $\left(243.00 \pm 0.03\right.$ to $\left.253.00 \pm 0.03{ }^{\circ} \mathrm{C}\right)$, flash point $\left(285.00 \pm 1.20\right.$ to $\left.304.00 \pm 1.10^{\circ} \mathrm{C}\right)$ and fire point $\left(345.00 \pm 1.10\right.$ to $\left.358.00 \pm 1.55^{\circ} \mathrm{C}\right)$ as well as iodine value $(113.00$ to $121.50 \mathrm{~g} / 100 \mathrm{~g})$ and fatty acid composition during the processing of the oil. The fatty acids detected in the oil samples were myristic, palmitic, stearic, oleic, arachidic, behenic, linoleic and linolenic acids. The predominant fatty acid was oleic acid (47.40-47.90\%) followed by linoleic acid $(26.36-30.44 \%)$ while the least fatty acid was linolenic acid (0.01-0.05\%).
\end{abstract}

Keywords: fluted pumpkin, seed oil, degumming, neutralisation, bleaching, fatty acid composition

\section{Introduction}

Cucurbitaceae is one of the largest floras which consist of nearly 100 genera and 750 species. The plant family is known for its great genetic diversity and wide spread adaptation which include tropical and sub-tropical regions, arid desert and temperate locations. Cucurbits are known for their high protein and oil content (Giwa et al., 2010).

The seed and seed oil characteristic of some members of the cucurbits are documented in literature and they are generally referred to as melons. Telfairia occidentalis is a member of the cucurbitaceae family, commonly called fluted pumpkin. Its common names include, Fluted guard, Colestillada (Spanish), Krobanko (Ghana), Gonugbe (Sierra Leone) and Ugu (South-East, Nigeria) (Chukwuonso et al., 2010). The crop is grown mainly for the leaves, which constitute an important component of the diet in many West African countries (Gill, 1992). Fluted pumpkin (T. occidentialis Hook F.) is one of the food crops with considerable value of energy and protein that is grown in Nigeria. It is a vine with large lobed leaves and long twisting tendrils (Chukwuonso et al., 2010; Okoli and Mgbeogu, 1983). Although pumpkin seeds are rich in oil storage reserves, it presently has very low commercial value as an oil seed but is poten-

*Author for correspondence; E-mail: joawande1@yahoo.com tially valuable as a high protein oil seed for human and animal food (Nkang et al., 2003). The seeds of fluted pumpkin are valuable both as an oil seed (54\%) and also as a protein source (27\%) with a fairly well balanced amino acid composition (Hamed et al., 2008; Akwaowo et al., 2000). Unfortunately, 78-91\% of the fruits wasted annually (Fagbemi et al., 2005).

There are many studies on the proximate composition and nutritive value of leaves and seeds of $T$. occidentalis (Effiong et al., 2009; Hamed et al., 2008; Akwaowo et al., 2000; Giami and Isichei, 1999; Giami and Bekebian, 1992; Asiegbu, 1987), scanty information is available on the physicochemical properties of the seed oil and fatty acid profile (Bello et al., 2011), but little or no information on physicochemical properties and fatty acid composition of the processed (refined) seed oil.

Oil seeds tend to contain a much larger proportion of solid material associated with the requiring careful reduction in size and usually some heat treatment before being processed or solvent extracted to recover the oil (Gunstone and Norris, 1983). The chemical composition of oil extract consequently gives a qualitative identification of oil, and is an important area in the selective application guide in the commercialization and utility of oil products (Salunkhe et al., 1992). A number of seed oils have been characterized for the identification 
of several fatty acids of nutritional and nutraceutical importance but the vast majority have not been adequately evaluated.

Like all vegetable oils, fluted pumpkin (T. occidentalis) seed oil is composed of triglycerides (98-99\%) and other substances in unsaponifiable fractions (nonglycerides) which are also known as the 'minor component' (NRC, 2001). Crude T. occidentalis seed oil produced by solvent extraction contains both oil-soluble and oil-insoluble substances that need to be removed (with minimum loss of oil, and damage to the nature of the oil 'glycerides' and tocopherol). The oil-insoluble materials may be removed through filtration. However, the soluble material must be removed by several methods which lead to production of edible oil. And such methods include degumming, neutralisation, bleaching and deodorization (Gunstone and Norris, 1983). Crude T. occidentalis seed oil contains phosphatides (hydratable and nonhydratable) as one of the soluble materials, hydratable one can be removed with $2-3 \%$ hot water while the non-hydratable ones are removed with addition of phosphoric or citric acid (Lusas, 2002; Gunstone and Norris, 1983). These phosphatides are referred to as gum and removal of this gum is called degumming.

The next stage is neutralisation which is the process that removes free fatty acids from the degummed oil. This is done by mixing a calculated volume of a specific concentration of caustic soda (sodium hydroxide) with the oil at a definite temperature $\left(60-80^{\circ} \mathrm{C}\right)$ and atmospheric pressure $\left(1.01325 \times 10^{4} \mathrm{~N} / \mathrm{M}^{2}\right)$, for a definite time and with prescribed agitation conditions. The alkali treatment is designed to remove the undesirable crude oil impurities without saponifying any degummed oil which would increase refining loss (Erickson et al., 1980). Vegetable oils generally contain colour pigments which are predominantly yellow, red and green. The yellow, orange and red pigments are known as 'carotenoids'. Other colours include chlorophyll, steroid, tocopherols and gozypoll (Bernardini, 1973). Colour pigment must be removed so as to produce oil of brighter colour acceptable to consumers and these pigments are removed from the oil with bleaching earth or fullers' earth (John, 1990) through a process known as bleaching.

The present work was aimed to assess the physicochemical properties and fatty acid composition of crude, degummed, neutralised and bleached Telfairia occidentalis seed oil with a view of establishing the effects of these processes on the parameters.

\section{Materials and Methods}

Collection and sample preparation . Fluted pumpkin fruits were bought from a local market in Owo, Ondo State, Nigeria. The fruits were sliced, and the seeds were removed. The seeds were cleaned and freed from unwanted materials before they were shelled manually. The seeds of good quality were sliced into pieces, sun dried and smoothly milled into powdery form. The flour was then stored into tight container prior to oil extraction.

Oil extraction. The powdered fluted pumpkin sample was then subjected to soxhlet extraction using hexane as solvent.

Ground seeds $(50 \mathrm{~g})$ were placed into a cellulose paper cone and extracted, using, hexane (B.P $65^{\circ} \mathrm{C}$ ) in a Soxhlet extractor for $8 \mathrm{~h}$. The oil was then recovered by simple distillation and residual solvent was removed by drying in a hot air oven at $45^{\circ} \mathrm{C}$ for $2 \mathrm{~h}$ (Erickson et al., 1980; Bligh and Dyer, 1959). The extracted oil was stored in an air-tight bottle for further analysis.

Refining process. The crude $T$. occidentalis seeds oil extracted was then subjected to degumming, neutralisation and bleaching processes.

Degumming process. $400 \mathrm{~cm}^{3}$ of the crude oil was heated to temperature of $70^{\circ} \mathrm{C}$ followed by addition of $0.80 \mathrm{~cm}^{3}$ of $50 \%$ phosphoric acid and the mixture was then vigorously stirred for $10 \mathrm{~min}$. Thereafter $10 \mathrm{~cm}^{3}$ of water heated to $80^{\circ} \mathrm{C}$ was added and whole mixture agitated for another $10 \mathrm{~min}$. The agitation was stopped and the mixture was allowed to stand undisturbed for $1 \mathrm{~h}$ so that the mixture was separated into two layers i.e. oil and gum. The gum was drained off while the oil obtained was termed as degummed oil (Salunkhe et al., 1992, Carlson, 1991; Erickson et al., 1980). The degummed oil was further subjected to alkali neutralisation.

Neutralisation process. Degummed oil $\left(200 \mathrm{~cm}^{3}\right)$ sample was heated up to $70^{\circ} \mathrm{C}$ with constant stirring in a beaker, then $3.3 \mathrm{~cm}^{3}$ of $3.59 \mathrm{M}$ (20 Baume) sodium hydroxide solution was added to the oil with vigorous stirring and the temperature rose to $90{ }^{\circ} \mathrm{C}$. Thereafter, $10 \mathrm{~cm}^{3}$ of saturated solution of sodium chloride (an electrolyte) was added and the resulting mixture was stirred vigorously at $90{ }^{\circ} \mathrm{C}$ for $30 \mathrm{~min}$. Then left undisturbed in a separating funnel for $6 \mathrm{~h}$ resulting into separated two layers, the lower layer which is known as 'soap stock' was then heated to $90{ }^{\circ} \mathrm{C}$ and washed with water then heated to $95^{\circ} \mathrm{C}$. The washing was done six 
consecutive times to remove any excess caustic soda and water soluble gum remaining in the oil (Salunkhe et al., 1992, Erickson et al., 1980). The resulting neutral oil was then dried in a hot air oven, and later cooled in the desiccators. The dried oil was further bleached.

Bleaching processes. Neutralised $\left(100 \mathrm{~cm}^{3}\right)$ oil was heated to $75^{\circ} \mathrm{C}$ with constant agitation. Then $1 \mathrm{~g}$ of the bleaching earth was added and the mixture was heated to $110{ }^{\circ} \mathrm{C}$ with constant stirring for $45 \mathrm{~min}$ (Salunkhe et al., 1992, Erickson et al., 1980). It was then filtered and the resulting oil was termed as bleached oil.

\section{Physicochemical characterisation of the oil samples.}

The crude, degummed, neutralised and bleached oil samples were analysed for physicochemical properties. The moisture content and specific gravity were determined according to AOAC (1990), while the refractive index was measured using Abbey Refractometer coupled with thermometer (ASTM, 1985). The colour was determined using Lovibond Tintometer (Model 520). The colour of crude oil was determined in half $\left(1 / 22^{\prime \prime}\right)$ inch cell while that of degummed, neutralised and bleached oils were determined in 1" inch cell. The flash and fire points were measured using GallenKamp Authomatic Pensky-Martens flash point and fire point tester with thermometer while the smoke point was determined using Cleveland Open Cup apparatus (Lawson, 1995; ASTM, 1985). The temperature at which turbidity was first detectable also measured using Palm Test turbidity tube (ASTM, 1985). The free fatty acid, acid value, saponification value and peroxide value were determined using methods described by AOAC (1990), while iodine value was determined by method described by Morris (1999) and Pearson (1976).

Fatty acids identification. The oil samples were converted to fatty acid methyl esters (FAMEs) using the method described by Oshodi (1996) and Hall (1982). The fatty acid methyl esters were analysed using an HP 6890 gas chromatograph fitted with flame ionization detector and powered with HP chemistation Rev.09.01 [206] software. The career gas was helium at pressure of 19 psi. The FAMEs sample $(1.5 \mu \mathrm{L})$ was injected and the separation was carried out on an HP capillary column (HP-INNowax; cross-linked PEG); 30.0 m length, $0.32 \mathrm{~mm}$ i.d., and $0.50 \mu \mathrm{m}$ film thickness. The oven temperature was held initially at $60{ }^{\circ} \mathrm{C}$ for $2 \mathrm{~min}$, increased from $180{ }^{\circ} \mathrm{C}$ at $12{ }^{\circ} \mathrm{C} / \mathrm{min}$ to $320^{\circ} \mathrm{C}$ at $14{ }^{\circ} \mathrm{C} / \mathrm{min}$ and then maintained at $320^{\circ} \mathrm{C}$ for $5.0 \mathrm{~min}$. The temperature of the injection port and the detector were set at
$250{ }^{\circ} \mathrm{C}$ and $300^{\circ} \mathrm{C}$, respectively. The peaks were identified by comparison with standard fatty acid methyl esters (ASTM, 1985).

\section{Results and Discussion}

Table 1 shows physicochemical parameter of crude, degummed, neutralised and bleached oils obtained from fluted pumpkin seeds. Fluted pumpkin seeds contain $42.26 \pm 0.20 \%$ crude oil and the oil is light yellow with colour unit of 20 in half inch cell. This high yield value indicates that the processing of the oil for industrial or edible purpose would be economical. The oil yield is lesser than 54\% reported for T. occidentalis (Akwaowa et al., 2000). There was no moisture in the crude sample analysed and this implied that the oil may have prolong shelf life. The colour of degummed, neutralised and bleached oil samples were 10.0, 8.0 and 5.0 lovibond unit, respectively, in one inch cell. This was calculated based on the expression $(5 \mathrm{R}+\mathrm{Y}-\mathrm{B})$ :

where:

$\mathrm{R}=$ the red pigment, $\mathrm{Y}=$ yellow pigment; $\mathrm{B}=$ blue pigment.

The progressive decrease in colour from crude oil to bleached oil was as a result of phosphoric acid used for degumming and bleaching earth specifically used to remove colour pigments during bleaching (Abitogun and Oshodi, 2010; Bernardini, 1973). There was no remarkable difference in the values of both specific gravity (0.923-0.924) and refractive index (1.474-1.475) of crude, degummed, neutralised and bleached oil samples. The specific gravities of the oil sample were slightly higher than the specific gravity $(0.913)$ of pumpkin seed kernel oil reported by Mohammed (2004). The refractive indices of the oil samples were slightly higher than 1.4721 reported for Adenopus breviflorus Benth seed oil (Akintayo and Bayer, 2002). The smoke point $\left({ }^{\circ} \mathrm{C}\right)$ for crude, degummed, neutralised and bleached oils were $243.00 \pm 0.03,248.00 \pm 0.01,250.00 \pm 0.02$ and $253.00 \pm 0.03$, respectively, while that of flash point $\left({ }^{\circ} \mathrm{C}\right)$ were $285.00 \pm 1.20,289.00 \pm 1.30,290.00 \pm 1.00$ and $304.00 \pm 1.10$ and that of fire points $\left({ }^{\circ} \mathrm{C}\right)$ were $345.00 \pm$ $1.10,350.00 \pm 1.25,353.00 \pm 1.20$ and $358.00 \pm 1.55$, respectively. The progressive increase in values of smoke, flash and fire points from crude oil to bleached oil might be as a result of removal of impurities such as volatile organic material and the residual extraction solvent during the oil processing (Erickson et al., 1980). The high smoke, flash and fire points of the oil suggest 
Table 1. Physicochemical parameters of crude, degummed, neutralised and bleached oils obtained from fluted pumpkin seeds

\begin{tabular}{lllll}
\hline \hline Parameters & Crude oil & Degummed oil & Neutralised oil & Bleached oil \\
\hline Specific gravity $\left(\right.$ at $\left.25{ }^{\circ} \mathrm{C}\right)$ & $0.924 \pm 0.002$ & $0.923 \pm 0.003$ & $0.923 \pm 0.003$ & $0.923 \pm 0.002$ \\
Refractive index $\left(\right.$ at $\left.25^{\circ} \mathrm{C}\right)$ & $1.475 \pm 0.002$ & $1.474 \pm 0.004$ & $1.474 \pm 0.003$ & $1.474 \pm 0.010$ \\
Moisture content $(\%)$ & $0.00 \pm 0.00$ & $0.00 \pm 0.00$ & 0.00 & $0.00 \pm 0.00$ \\
Turbidity point $(\mathrm{JTU})$ & $9.00 \pm 0.20$ & $5.00 \pm 0.25$ & $5.00 \pm 0.15$ & $4.00 \pm 0.10$ \\
Smoke point $\left({ }^{\circ} \mathrm{C}\right)$ & $243.00 \pm 0.03$ & $248.00 \pm 0.01$ & $250.00 \pm 0.02$ & $253.00 \pm 0.03$ \\
Flash point $\left({ }^{\circ} \mathrm{C}\right)$ & $285.00 \pm 1.20$ & $289.00 \pm 1.30$ & $290.00 \pm 1.00$ & $304.00 \pm 1.10$ \\
Fire point $\left({ }^{\circ} \mathrm{C}\right)$ & $345.00 \pm 1.10$ & $350.00 \pm 1.25$ & $353.00 \pm 1.20$ & $358.00 \pm 1.55$ \\
Colour $($ unit) & 20.0 & 10.0 & 8.0 & 5.0 \\
Free fatty acid $(\%)$ as Oleic & $1.83 \pm 0.10$ & $1.08 \pm 0.20$ & $0.48 \pm 0.10$ & $0.60 \pm 0.12$ \\
Acid value $(\mathrm{mg} / \mathrm{KOH} / \mathrm{g})$ & $3.64 \pm 0.29$ & $2.14 \pm 0.20$ & $0.94 \pm 0.25$ & $1.18 \pm 0.14$ \\
Iodine value $(\mathrm{g} / 100 \mathrm{~g})$ & $113.00 \pm 0.17$ & $115.70 \pm 0.12$ & $116.20 \pm 0.18$ & $121.50 \pm 0.20$ \\
Peroxide value $(\mathrm{meq}$ peroxide/ $/ \mathrm{kg})$ & $1.80 \pm 0.28$ & $0.90 \pm 0.12$ & $0.50 \pm 0.07$ & $0.30 \pm 0.19$ \\
Saponification value $(\mathrm{mg} / \mathrm{KOH} / \mathrm{g}$ oil) & $198.20 \pm 1.82$ & $194.30 \pm 1.09$ & $186.60 \pm 1.40$ & $180.00 \pm 0.06$ \\
Yield $(\%)=42.26 \pm 0.20$ & & & & \\
\hline \hline
\end{tabular}

Mean \pm standard deviation of triplicate determination.

that it can be suitable for deep frying purpose (Bello et al., 2011; Akintayo and Bayer, 2002). Free fatty acid (FFA) and acid values are among the characteristics features that are necessary for the confirmation of the identity and edibility of oil. FFA can stimulate hydrolytic deterioration of oils to form off- flavour components. The free fatty acid ( $\%$ oleic acid) for the crude, degummed, neutralised and bleached oils were $1.83 \pm 0.10,1.08 \pm 0.20$, $0.48 \pm 0.10$ and $0.60 \pm 0.12$, respectively while acid values $(\mathrm{mgKOH} / \mathrm{g})$ were $3.64 \pm 0.29,2.14 \pm 0.15,0.94 \pm 0.25$ and $1.18 \pm 0.14$, respectively. These values are relatively low that suggests application of the oil as good edible oil (Akintayo and Bayer, 2002).

It is noted that oil samples containing low FFA give high smoke, flash and fire points and this quality will enhance the suitability of the oil for deep fry cooking (Akintayo and Bayer, 2002). The FFA and acid value decreased from crude oil to neutralised oil but sudden increase is observed in bleached oil. The decrease in FFA and acid value is due to the effective use of caustic alkali in neutralisation of the oil sample which led to reduction in the free fatty acids, acid values and other impurities while the increase in FFA and acid values of bleached oil is a result of acidic nature of bleaching earth used for colour removal (Salunkhe et al., 1992; Bernardini, 1973). The acid values of the samples were lower than the minimum acceptable value of $4.0 \%$ (for crude oil) recommended by the Codex Alimentarius Commission for oil seed (Abayeh et al., 1998). The peroxide values (meq/peroxide $/ \mathrm{kg}$ ) of crude, degummed, neutralised and bleached oil are $1.80 \pm 0.28,0.90 \pm 0.12$, $0.50 \pm 0.07$ and $0.30 \pm 0.19$, respectively. The low value was an indication that the oil has a high resistance to peroxidation and low rate of spoilage (Abayeh et al., 1998). This value is low as compared to the maximum acceptable value of $10 \mathrm{meq} / \mathrm{KOH} / \mathrm{g}$ set by the Codex Alimentarius Commission for edible oils (Abayeh et al., 1998). The oil is thus stable and will not easily go rancid. The iodine value $(\mathrm{g} / 100 \mathrm{~g})$ of the crude, degummed, neutralised and bleached oils are 113.00 $\pm 0.17,115.70 \pm 0.12,116.20 \pm 0.18$ and $121.50 \pm 0.20$, respectively. The iodine value of the oil samples classified the oil among the semi drying oil (Fernando and Akujobi, 1987). In addition, the high iodine value of the oils indicates that the oil contains more unsaturated fatty acid than saturated fatty acid (Nielsen, 1994) since iodine value is a measure of the extent of unsaturation of fatty acid present in fats and oils (Nielsen, 1994). The iodine values are comparable to iodine value of $112.10 \mathrm{~g} / 100 \mathrm{~g}$ for Adenopus Benth seed oil (Das et al., 2002) and $121.03 \mathrm{~g} / 100 \mathrm{~g}$ for African pea, Dacryodes edulis (Ajiwe et al., 1997). On the other hand, the values obtained are higher than $83.50 \mathrm{~g} / 100 \mathrm{~g}$ reported as iodine value of Moringa oleifera seed oil (Ogbunugafor et al., 2011). Moreover, the iodine value of the oil increases progressively at each stage of the processing owing to gradual removal of some impurities present in it. The saponification values $(\mathrm{mg} / \mathrm{KOH} / \mathrm{g}$ oil) of the crude, 
degummed, neutralised and bleached oil samples are $198.20 \pm 1.82,194.30 \pm 1.09,186.60 \pm 1.40$ and $180.00 \pm 0.06$, respectively. The saponification values are relatively lower as compared to palm kernel oil $(253.781 \mathrm{mg} /$ $\mathrm{KOH} / \mathrm{g}$ ) (Arawande, 2013) and this indicates that the oil will not be good for soap making.

Table 2 depicts the fatty acid composition of crude, degummed, neutralised and bleached oils obtained from fluted pumpkin (T. occidentalis) seeds. The fatty acids detected in the crude, degummed, neutralised and bleached oil samples are myristic, palmitic, stearic, arachidic, behenic, palmitoleic, oleic, linoleic and linolenic acids. The amount (\%) of fatty acids in the crude oil are: myristic, 0.12; palmitic acid, 10.80; stearic acid, 0.24; arachidic acid, 1.17; behenic acid, 0.42; oleic acid, 47.40; linoleic acid, 26.36 and linolenic acid, 0.01. Also, the values $(\%)$ of these fatty acids in degummed oil are myristic acid (0.30), palmitic acid (12.40), stearic acid (1.65), arachidic acid (1.70), behenic acid (0.46), palmitoleic acid (0.17), oleic acid (47.86), linoleic acid (27.36) and linolenic acid (0.01), respectively. In addition, the following fatty acids are present in the neutralised oil sample, myristic acid $(0.45 \%)$, palmitic acid (13.00\%), stearic acid (1.80\%), arachidic acid (1.83\%), behenic acid ( $0.51 \%)$, palmitoleic acid $(0.25 \%)$, oleic acid (47.90\%), linoleic acid (28.20\%) and linolenic acid $(0.01 \%)$. Moreover the amount (\%) of fatty acids present in the bleached oil is reported as follows: myristic acid is 0.63 , palmitic acid is 13.57 , stearic acid is 2.33 , arachidic acid is 2.00 , behenic acid is 0.62 , palmitoleic acid is 0.30 , oleic acid is 49.02 , linoleic acid is 30.44 and linolenic acid is 0.05 . In all the oil samples, oleic acid has the highest composition and next to it is linoleic acid. Palmitoleic acid was not detected in the crude oil but was detected in degummed, neutralised and bleached oil samples. It is observed that fatty acid value increased as the processing progressed from one stage to another. The predominant fatty acid was oleic acid (47.40$47.90 \%$ ) and this high content suggest the oil to have ability to reduce incidence of coronary heart disease (CHD) because oleic acid decreases total cholesterol (10\%) and LDL cholesterol (Dennys et al., 2006). Also the high level of unsaturated fatty acids content of the oil in conjunction with its low free fatty acid and acid values confirm the reasons for its edibility.

Table 3 gives the summary of the total fatty composition of the oil. The values for saturated fatty acid in crude, degummed, neutralised and bleached oils are $12.75,16.52,17.59$ and $19.15 \%$, respectively, that of mono-unsaturated fatty acids are 47.40, 48.03, 48.15 and $49.32 \%$, respectively, while that of polyunsaturated fatty acids are 26.37, 27.37, 28.21 and 30.49\%, respectively. The total fatty acid in crude, degummed, neutralised and bleached oils are 86.52, 91.92, 93.95 and $98.96 \%$, respectively. There is progressive increase in the saturated, monounsaturated, polyunsaturated and total fatty acid of fluted pumpkin seed oil during processing from crude oil to bleached oil. In addition, these results show that the proportion of unsaturated fatty acids was much higher i.e., $73.77 \%-79.81 \%$, and that of saturated fatty acids was less than $25 \%$. This is in accordance with the values reported for other vegetable oils (Salman and Tanver, 2005; Raie et al., 1992) which is characteristics for these oils.

Table 2. Fatty acid composition of crude, degummed, neutralised and bleached oils obtained from fluted pumpkin seeds

\begin{tabular}{lllllll}
\hline \hline $\begin{array}{l}\text { Fatty acid } \\
\text { methylester }\end{array}$ & Fatty acids & Carbon number & $\begin{array}{l}\text { Crude oil } \\
(\%)\end{array}$ & $\begin{array}{l}\text { Degummed oil } \\
(\%)\end{array}$ & $\begin{array}{l}\text { Neutralised oil } \\
(\%)\end{array}$ & $\begin{array}{l}\text { Bleached oil } \\
(\%)\end{array}$ \\
\hline Myristate & Myristic & $14: 0$ & 0.12 & 0.30 & 0.45 & 0.63 \\
Palmitate & Palmitic & $16: 0$ & 10.80 & 12.40 & 13.00 & 13.57 \\
Stearate & Stearic & $18: 0$ & 0.24 & 1.65 & 1.80 & 2.33 \\
Arachidate & Arachidic & $20: 0$ & 1.17 & 1.70 & 1.83 & 2.00 \\
Behenoate & Behenic & 22.0 & 0.42 & 0.46 & 0.51 & 0.62 \\
Palmitoleate & Palmitoleic & $16: 1$ & N.D & 0.17 & 0.25 & 0.30 \\
Oleate & Oleic & $18: 1$ & 47.40 & 47.86 & 47.90 & 49.02 \\
Linoleate & Linoleic & $18: 2$ & 26.36 & 27.36 & 28.20 & 30.44 \\
Linolenate & Linolenic & $18: 3$ & 0.01 & 0.01 & 0.01 & 0.05 \\
\hline \hline
\end{tabular}

$\mathrm{ND}=$ not detected. 
Table 3. Summary of fatty acid composition of crude, degummed, neutralised and bleached oils obtained from fluted pumpkin seeds

\begin{tabular}{lllll}
\hline \hline Oil sample & $\begin{array}{l}\text { Saturated } \\
\text { fatty acid } \\
(\%)\end{array}$ & $\begin{array}{l}\text { Mono- } \\
\text { unsaturated } \\
\text { fatty acid } \\
(\%)\end{array}$ & $\begin{array}{l}\text { Poly- } \\
\text { unsaturated } \\
\text { fatty acid } \\
(\%)\end{array}$ & $\begin{array}{l}\text { Total } \\
(\%)\end{array}$ \\
\hline Crude & 12.75 & 47.40 & 26.37 & 86.52 \\
Degummed & 16.52 & 48.03 & 27.37 & 91.92 \\
Neutralised & 17.59 & 48.15 & 28.21 & 93.95 \\
Bleached & 19.15 & 49.32 & 30.49 & 98.96 \\
\hline \hline
\end{tabular}

\section{Conclusion}

Processing of fluted pumpkin seed oil from crude to bleached oil increases iodine value, smoke point, flash point, fire point, saturated, monounsaturated, polyunsaturated and total fatty acid composition of the oil. Whereas, processing of the oil from crude oil to bleached oil resulted in decrease in values of saponification, peroxide, colour and turbidity. It is obvious that if the bleached oil is deodourized, it will supply essential fatty acid needed in the body and the final refined oil will be of high quality in terms of physicochemical properties and this will enhance its edibility. It is further suggested that the bleached oil should be deodourised and analysed for physicochemical properties and fatty acid composition.

\section{References}

Abayeh, O.J., Aina, E.A., Okonghae, C.O. 1998. Oil content and oil quality characteristics of some Nigerian oil seeds. Journal of Pure and Applied Sciences, 1: 17-23.

Abitogun, A.S., Oshodi, A.A. 2010. Effects of degumming and bleaching on physicochemical properties of crude sunflower oil seeds. Journal of Chemical Society of Nigeria, 35: 57-61.

Ajiwe, V.I.E., Okeke, C.A., Nnabuike, B., Ogunleye, G.A., Elebo, E. 1997. Application of oil extracted from African star apple (Chrysophyllum africanum), horse eye bean (Mucuna sloanei) and African pear (Dacryodes edulis). Bioresource Technology, 59: 259-261.

Akintayo, E.T., Bayer, E. 2002. Charaterisation and some possible uses of Plukenetia conophora and Adenopus breviflorus seeds and seed oils. Boiresource Technology, 85: 95-97.

Akwaowo, E.U., Ndon, B.A., Etuke, E.U. 2000. Minerals and antinutrients in fluted pumpkin (Telfairia occidentalis Hook). Food Chemistry, 70: 235-240.

Alfawaz, M.A. 2004. Chemical composition and oil characteristics of Pumpkin (Cucurbita maxima) seed kernels. Food Science and Agriculture Research Centre, King Saud University, Research Bulletin No. 129, 5-18.

AOAC, 1990. Official Methods of Analysis, pp. 12501255, Association of Official Analytical Chemist, Washington D.C., USA.

Arawande, J.O. 2013. Antioxidative Activities of Extract of Fruit Peels and Vegetables on Edible Oils. Ph.D. Thesis, 61 pp., Federal University of Technology, Akure, Ondo State, Nigeria.

Asiegbu, I.E. 1987. Some biochemical evaluation of fluted pumpkin seed. Journal of Science, Food and Agriculture, 40: 151-155.

ASTM, 1985. American Society for Testing Materials. ASTM Publication, pp. 31-36, 40-48.

Bello, M.O., Akindele, T.L., Adeoye, D.O., Oladimeji, A.O. 2011. Physicochemical properties and fatty acids profile of seed oil of Telfairia occidentalis Hook, F. International Journal of Basic and Applied Sciences, 11: 9-14.

Bernardini, E. 1973. Oil and Fat Technology, pp. 709719. Technologie Publishing House, S.R.L. Rome, Italy.

Bligh, E.G., Dyer, W.J. 1959. A rapid method of total lipid extraction and purification. Canadian Journal of Biochemistry and Physiology, 37: 911-917.

Carlson, K.F. 1991. Fats and oils processing. INFORM, 2: 1046-1060.

Chukwuonso, E.C.C.E., Paschal, C.U., Lawrence, U.S.E. 2010. Dietary incorporation of boiled fluted pumpkin (Telfairia occidetalis Hook F.) seeds 1: Growth and toxicity in rats. Research Journal of Biological Sciences, 5: 140-145.

Das, M., Das, S.K., Suthar, S.H. 2002. Composition of seeds and characteristics of oil from karingda [Citrullus lanatus (Thumb) Mansf]. International Journal of Food Science \& Technology, 37: 893896.

Dennys, E.C.C., Andre, G.V.C., Maria do, C.G.P., SergioMatta, D.S., Marco, T.C.S., Neuza, M.B.C. 2006. Lipid profile of rats fed high-fat diets based on flaxseed, peanut, trout, or chicken skin. Nutrition, 22: 197-205.

Effiong, G.S., Ogban, P.I., Ibia, T.O., Adam, A.A. 2009. Evaluation of nutrient-supplying potential of fluted pumpkin (Telfairia occidetalis Hook F.) and Okra 
(Abelmoschus esculentus) (L.) Moench. Academic Journal of Plant Sciences, 2: 209-214.

Erickson, D.R., Pryde, E.H., Brekks, O.L.,Mount, T.L., Falb, R.A. 1980. Handbook of Soy Oil Processing and Utilization, pp. 65-68, American Soybean Association St. Louis and the American Oil Chemists Society, Champaign, Illinois, USA.

Fagbemi, T.N., Oshodi, A.A., Ipinmoroti, K.O. 2005. Processing effects on some antinutritional factors and in vitro multienzyme protein digestibility (IVPD) of three tropical seeds: Breadnut (Artocarpus altilis), Cashewnut (Anacardium occidentale) and Fluted pumpkin (Telfairia occidentalis). Pakistan Journal of Nutrition, 4: 250-256.

Fernando, C.E.C., Akujobi, E.O. 1987. Chemical analysis of selected vegetable oils and fats of Sokoto State of Nigeria. Journal of Basic and Applied Sciences, 1: 11-15.

Giami, S.Y., Bekebian, D.A. 1992. Proximate composition and functional properties of raw and processed full fat fluted pumpkin (Telfairia occidentalis) seed flour. Journal of Science, Food and Agriculture, 59: 321-325.

Giami, S.Y., Isichei, I. 1999. Preparation and properties of flours and protein concentrated from raw, fermented and germinated fluted pumpkin (Telfairia occidetalis Hook) seeds. Plant Foods for Human Nutrition, 54: 67-77.

Gill, L.S. 1992. Ethnomedical Uses of Plants in Nigeria, pp. 165-248, Universty of Benin City, Nigeria.

Giwa, S., Abdullah, L.C., Adam, N.M. 2010. Egnsi (Citrullus colocynthis L.) seed oil as potential biodiesel feedstock. Energies, 3: 607-618.

Gunstone, F.D., Norris, F.A. 1983. Lipids in Food: Chemistry, Biochemistry and Technology, pp. 58-68, Pergamon Press, New York, USA.

Hall, G.M. 1982. Silage from tropical fish. Lipid behavior. Journal of Food Technology, 21: 45-54.

Hamed, S.Y., El-Hassan, N.M., Hassan, A.B., Eltayeb, M.M., Babiker, E.E. 2008. Nutritional evaluation and physicochemical properties of processed pumpkin (Telfairia occidentalis Hook) seed flour. Pakistan Journal of Nutrition, 7: 330-334.

John, M.D. 1990. Principles of Food Chemistry, $2^{\text {nd }}$ edition, pp. 57-70, Van Nostrand Reinhold, New York, USA.
Lawson, H. 1995. Food Oils and Fats-Technology, Utilization and Nutrition, pp. 65-69, Springer, USA.

Lusas, E.W. 2002. Oil seeds and oil bearing materials. In: Handbook of Cereal Science and Technology, K. Kulp and J. G. Porte, Jr. (eds), pp. 297-362, Marcel Dekker Inc., New York, USA.

Morris, B., Jacobs. 1999. The Chemical Analysis of Food and Food Product, pp. 357-390, $3^{\text {rd }}$ edition, CBS Publisher, New Dehli, India.

Nielsen, S.S. 1994. Introduction to the Chemical Analysis of Foods, pp. 257-390, Champan \& Hall, New York, NY, USA.

Nkang, A., Omokaro, D., Egbe, A., Amanke, G. 2003. Variation in fatty acid proportions during desiccation of Telfairia occidentalis seeds harvested at physiological and agronomic maturity. African Journal of Biotechnology, 2: 33-39.

NRC, 2001. Nutrient Requirement of Dairy Cattle, 1333 pp., $7^{\text {th }}$ revised edition, National Academies Press, National Research Council, Washington DC., USA.

Ogbunugafor, H.A., Eneh, F.U., Ozumba, A.N., IgwoEzikpe, M.N., Okpuzor, J.,Igwilo, I.O., Adenekan, S.O., Onyekwelu, O.A. 2011. Physicochemical and antioxidant properties of Moringa oleifera seed oil. Pakistan Journal of Nutrition, 10: 409-414.

Okoli, B.E., Mgbeogu, C.M. 1983. Fluted pumpkin (Telfairia occidentalis): West African vegetable crop. Economic Botany, 37: 145-149.

Oshodi, A.A. 1996. Amino acid and fatty acid composition of Adenopus breveflorus Benth seed. International Journal of Food Sciences and Nutrition, 47: 295-298.

Pearson, D. 1976. The Chemical Analysis of Foods. pp. 6-14, 200-227, $7^{\text {th }}$ edition, Churchill Living Stone, London, UK.

Raie, M.Y., Ijaz, A., Akhtar, M.W. 1992. Distribution of fatty acids in triglycerides of Carum capticum. Pakistan Academic Science, 26: 199-206.

Salman, R., Tanver, A.C. 2005. Intramolecular fatty acids distribution in the triglyceride of Hordeum vulgare. Pakistan Journal of Scientific and Industrial Research, 48: 389-392.

Salunkhe, D.K., Chavan, R.W., Adsule, Kadam, S.S. 1992. World Oil Seed, Chemistry Technology and Utilization, pp. 148-192, An AVI Book Published by Van Nostrand Reinhold, New York, USA. 